\title{
Long-term Impact of No Tillage in Two Intensified Crop Rotations on Different Soil Organic Matter Fractions in Argentine Rolling Pampa
}

\author{
A. Irizar ${ }^{1, *}$, A. Andriulo ${ }^{1}$ and B. Mary ${ }^{2}$ \\ ${ }^{1}$ Estación Experimental Agropecuaria Pergamino, INTA, ruta $32 \mathrm{~km}$ 4,5 - CP 2700 - Pergamino, Buenos Aires, Argentina \\ ${ }^{2} I N R A$, US 1158 Agro-Impact, site de Laon, Pôle du Griffon, 180 rue Pierre-Gilles de Gennes F-02000, Barenton- \\ Bugny, France
}

\begin{abstract}
It is expected that the agricultural intensification occurred in recent decades in the Argentine Rolling Pampa significantly alters the SOM reserves. Therefore, it is necessary to identify soil organic carbon $(\mathrm{C})$ and nitrogen $(\mathrm{N})$ fractions to understand the functionality and stabilization of these reserves. Our objectives were to study the NT effect in two crop rotations, corn-double cropped wheat/soybean (MWS) and double cropped wheat/soybean (WS) on: 1) SOM and its particle size and biological fractions contents, 2) $\mathrm{C}$ and $\mathrm{N}$ stubble biomass and 3) some soil properties in order to explain the SOM differences found. The larger biomass residue remaining on the soil surface under NT promoted higher aggregate stability and lower soil temperature and $\mathrm{pH}$. At $0-5 \mathrm{~cm}$ soil depth, $\mathrm{NT}$ exhibited higher $\mathrm{C}$ and $\mathrm{N}$ contents, for both uncomplexed and intimately associated to the mineral components fractions. However, the results indicated variations in the SOM protection according to the rotation: in MWS the high aggregate stability showed better physical protection, while in WS the greater cation exchange capacity and the lower value of $\mathrm{N}$ released by anaerobic incubation would indicate the presence of transformed SOM. At $5-20 \mathrm{~cm}$ soil depth, only in WS, C microbial biomass was higher with a low metabolic rate, indicating again the presence of highly decomposed SOM. The results obtained in WS under NT would indicate the possibility of achieving slower recycled of the SOM.
\end{abstract}

Keywords: No tillage, Crop rotations, soil organic matter fractions.

\section{INTRODUCTION}

One of the main agronomic challenges in degraded agroecosystems is to find crop systems that maintain or increase the reserves of soil organic matter (SOM), to contribute to the mitigation of the greenhouse effect, enable progress in food security and improve the environment.

In the Rolling Pampa, the most important cropping region of Argentina, important changes took place in the production systems during the 1970s: the agriculture cycles, which traditionally alternated with pasture cycles, began to be transformed into continuous agriculture. Indeed, the relationship between the cultivated surface and the surface with pastures decreased at about $4 \%$ annually [1]. In addition, soybean was introduced as a single annual crop or as a double crop accompanying wheat and the work of the soil was intensified: primary work was carried out with moldboard plow and plow up to about $20 \mathrm{~cm}$ deep. Towards the end of the $1980 \mathrm{~s}$, the soils of this region had already suffered the loss of $40-60 \%$ of the topsoil SOM [2].

No-tillage (NT) practices were first introduced in the middle of 1970 s to provide several environmental benefits

*Address correspondence to this author at the Estación Experimental Agropecuaria Pergamino, INTA, ruta $32 \mathrm{~km} \mathrm{4,5} \mathrm{-} \mathrm{CP} 2700$ - Pergamino, Buenos Aires, Argentina; Tel: (54) 2477 439029; Fax: (54) 2477 439047;

E-mail: airizar@pergamino.inta.gov.ar such as the reduction of soil erosion, the improvement of the soil structure and infiltration, and the conservation of soil water. Until 1988, the agricultural area under NT was only $0.02 \%$ of the total national agricultural surface. After that, NT has continued to develop and evolve in recent decades and the Argentine Rolling Pampa has become one of the world's fastest growing areas of NT adoption. Currently, the agriculture surface under NT represents $78.5 \%$ of the national agricultural area [3]. In the 1990s, the agricultural intensification of the Argentine Rolling Pampa advanced towards simplified production schemes under NT, with springsummer species, especially soybean $(70 \%$ of the agricultural surface), and, secondarily, maize ( $15 \%$ of the agricultural area), and wheat preceding soybean some years, or otherwise, the soil remaining fallow between the two summer crops. About $80 \%$ of soybean, $61 \%$ of wheat and $72 \%$ of corn are cultivated under continuous NT [4]. This general adoption of NT occurred together with a high dependence on broad spectrum herbicides and increasing mineral nitrogen fertilization rates related to maize and wheat production $[5$, 6]. Since the early 1990s, conventional tillage in this region has consisted of chisel plow (CP) as a primary tillage to a depth of 15 to $20 \mathrm{~cm}$ and disking and/or harrowing or field cultivator as secondary tillage to a depth of $10 \mathrm{~cm}$ to prepare a suitable seedbed following plowing. Usually, soybean is drilled as a continuous monoculture or, to a lesser extent, rotated in more intensive cropping, doubled-cropped after wheat or in integration with maize and wheat in sequences 
with three or four cultures every two or three years, maizedouble cropped wheat/soybean or doubled-cropped wheat/soybean-maize-soybean, respectively. It is expected that the agricultural intensification occurred in recent decades significantly alters the SOM reserves [7].

The silty loam soils of the Argentine Rolling Pampa under NT with dominance of soybean present a progressive decrease in their physical, chemical and biological fertility [8-10]. The main causes of such decrease include the long periods of fall-winter fallow [11], the low annual carbon (C) input to the soil $\left(2-3 \mathrm{Mg} \mathrm{C}^{-1}\right.$ year $\left.^{-1}\right)[11,12]$ and the enhancement of the mineralization of SOM by products of the biological fixation of nitrogen $(\mathrm{N})$, which lead to soil $\mathrm{pH}$ values close to neutrality, which favors decomposing microbial activity $[13,14]$. In addition, this crop system presents little soil coverage and low stability of the structure, trends to compaction, reduces the infiltration rate due to the presence of a laminar structure with a preferentially horizontal orientation of pores [15], produces a significant contribution of $\mathrm{N}$ (up to $36 \mathrm{~kg}$ ha year ${ }^{-1}$ ) to the groundwater [16] and promotes the further loss of $\approx 20 \mathrm{~kg} \mathrm{~N} \mathrm{ha}^{-1}$ year $^{-1}$ through runoff during rainy periods $[17,18]$.

On the other hand, the crop rotations under NT present SOM reserves higher than those under $\mathrm{CP}$, suggesting that the continuous practice of NT in the Rolling Pampa can reduce $\mathrm{CO}_{2}$ emissions and $\mathrm{N}$ losses to adjacent systems [11]. Therefore, it is necessary to improve the characterization of SOM stabilization in these intensified sequences to contribute to the achievement of sustainable agrosystems.

Our objectives were to study the NT effect in two crop rotations, maize-double cropped wheat/soybean (MWS) and double cropped wheat/soybean (WS), on: 1) SOM and its particle size and biological fractions contents, 2) $\mathrm{C}$ and $\mathrm{N}$ stubble biomass and 3) some soil properties, in order to explain the SOM differences found.

\section{MATERIALS AND METHODOLOGY}

\section{Study Site and Experimental Design}

The study was conducted at the Pergamino Experimental Station of the Instituto Nacional de Tecnología Agropecuaria of Argentina (INTA) ( $33^{\circ} 51^{\prime} \mathrm{S}$; $\left.60^{\circ} 40^{\prime} \mathrm{W}\right)$, where the climate is temperate humid without a dry season and with a hot summer [19]. The mean annual temperature is $16.7^{\circ} \mathrm{C}$ and the mean annual rainfall for the $1910-2010$ period was 971 $\mathrm{mm}$ (Agroclimatological network database, INTA). The area is covered by a fine, illitic, thermic Typic Argiudoll (US Soil Taxonomy), Luvic Phaeozem (WRB) of the Pergamino Series, without water erosion phases (soil slope $<0.3 \%$ ), and the texture of the A horizon is silty loam with $23 \%$ and $64 \%$ clay and silt, respectively [20].

Two assays of crop sequences were carried out in a 4.5ha plot: the maize-double cropped wheat/soybean rotation (MWS) began in 1979, and the double cropped wheat/soybean (WS) was added in 1983. Each assay presented a completely randomized block design. The main plot was $45 \mathrm{~m}$ long by $14 \mathrm{~m}$ wide, and the tillage systems were randomized in the main plots. The treatments analyzed in this study were CP and NT. Under CP, the soil was chiseled at a depth of $15 \mathrm{~cm}$ and disk- and teeth-harrowed at a depth of $10 \mathrm{~cm}$ in late June every year, whereas, under NT, only a narrow $(0-5 \mathrm{~cm})$ strip of soil was drilled to deposit the crop seeds. In both tillage systems, weeds were chemically controlled and no previous old plowed soil was recorded under the farm work depth. Wheat and maize were fertilized with 90 and $100 \mathrm{~kg} \mathrm{~N} \mathrm{ha}^{-1}$, respectively. In addition, maize and wheat were fertilized with $12 \mathrm{~kg}$ of phosphorus ha- ${ }^{-1}$.

\section{Soil and Plant Measurements}

In June 2008, before carrying out the tillage previous to maize in MWS and to wheat in WS, soil samples were taken at three depths: $0-5,5-10$ and 10-20 cm. Three sites were chosen at random for sub-sampling in each of the treatments, avoiding visible wheel tracks. Then, disturbed samples were dried in an oven at $30^{\circ} \mathrm{C}$ and sieved to $2 \mathrm{~mm}$. SOM particulate labile fractions (fraction $>53 \mu \mathrm{m}$ : particulate organic $\mathrm{C}$ (POC) and particulate organic N (PON)) were determined by the method of Cambardella and Elliot [21], replacing chemical dispersion of the original method by mechanical water agitation with glass balls [22]. Soil organic C (SOC), soil organic N (SON), POC and PON were analyzed by dry combustion using an elemental analyzer for $\mathrm{C}$ and $\mathrm{N}$ (LECO). Mineral associated C (MAC) and mineral associated $\mathrm{N}$ (MAN) were obtained by difference between SOC and POC and between SON and PON, respectively. Soil pH in $0.02 \mathrm{M} \mathrm{CaCl}_{2}$ was determined electrometrically using a soil solution proportion of 1:2.5 and cation exchange capacity (CEC) using Soil Survey Laboratory Staff method [23]. Soil aggregate stability (AS) and biological properties were analyzed at the $0-5$ and $5-20 \mathrm{~cm}$ layers. AS for aggregates $>$ $0.5 \mathrm{~mm}$ diameter was determined with the Douglas and Goss [24] method with slight modifications. The stability index was calculated with Kemper's [25] procedure:

$$
A S=\frac{\text { Dry weight aggregates }>0.5 \mathrm{~mm}}{\text { Initial dry weight aggregates }} \times 100
$$

The values assigned to AS were as follows: AS $<20 \%$ : unstable; AS between 20 and $40 \%$ : moderately stable, and AS $>40 \%$ : stable.

The biological properties analyzed were: (1) microbial biomass carbon (MBC), using the fumigation-extraction method [26, 27]; (2) basal respiration (BR) [28], and from the data obtained, the metabolic quotient $\left(\mathrm{qCO}_{2}\right)$ and $\mathrm{MBC} / \mathrm{SOC}$ ratio [29] were calculated; and (3) incubated anaerobic nitrogen (IAN), for which the samples were incubated in anaerobiosis for 7 days at $40^{\circ} \mathrm{C}$ [30]. The $\mathrm{N}^{-\mathrm{NH}_{4}}{ }^{+}$ released during the incubation period was determined by micro steam distillation [31].

Soil bulk density (BD) was determined by the cylinder method [32]. In a place adjacent to the disturbed sample, a small pit of $0-30 \mathrm{~cm}$ depth was opened and a cylinder was extracted at each depth. The cylinder, which had a volume of $58.9 \mathrm{~cm}^{3}$, was placed vertically at $0-5 \mathrm{~cm}$, and horizontally at the other two soil depths. All the samples were dried in an oven at $105^{\circ} \mathrm{C}$ to constant weight and density was calculated according to the internal diameter $(5 \mathrm{~cm})$ and height $(3 \mathrm{~cm})$ of the cylinder.

Disk permeameters were used to characterize steady-state infiltration rates (Ir) at $0 \mathrm{~cm}$ tension. Infiltration measurements were conducted near the three randomly selected sites of each plot. A 5-mm layer of sand was spread on the exposed area and leveled to ensure proper contact with the 
plate. These measurements were performed on the surface soil for $60 \mathrm{~min}$ to reach steady-state conditions [33].

Soil temperature and soil water content were measured from August $8^{\text {th }} 2008$ to January $9^{\text {th }} 2009$. Thermochronn iButton sensors were used for continuous recording of temperature. These sensors recorded changes of $0.5^{\circ} \mathrm{C}$ in soil temperature in a -30 to $70^{\circ} \mathrm{C}$ range. These sensors were scheduled to take measurements every 2 hours and placed at the $10 \mathrm{~cm}$ soil depth. For the recording of water content, soil Watermark probes were used. These probes provide water potential values in the measurement range from -10 to -200 $\mathrm{kPa}$. The readings were performed twice weekly in the morning and, as with temperature sensors, probes were placed at the $10 \mathrm{~cm}$ soil depth. To convert water potential readings into volumetric moisture content, a water characteristic curve was constructed using water tension tables and pressure plates.

On the other hand, during the fallow period after soybean, stubble was sampled near the three random sites of each plot, and the samples were taken with a ring of $0.25 \mathrm{~m}^{2}$. Then, the samples were dried at $30^{\circ} \mathrm{C}$, ground, sieved to 0.05 $\mathrm{mm}$ and homogenized, and $\mathrm{C}$ and $\mathrm{N}$ contents were analyzed by dry combustion using an elemental analyzer (LECO). The $\mathrm{C}$ and $\mathrm{N}$ of the stubble biomass were calculated in $\mathrm{Mg} \mathrm{ha}^{-1}$.

There were no significant differences between the tillage systems for the grain yields of each crop for the periods analyzed (1980-2008 and 1984-2008 in MWS and WS, respectively). Grain yields were used to estimate the $\mathrm{C}$ and $\mathrm{N}$ annually contributions. The harvest indexes used were 0.50 , 0.34 and 0.38 [34] for maize, wheat and soybean, respectively. The assumed root masses were $30 \%$ for all crops in relation to total aboveground biomass, and including rhizodeposition [35]. The $\mathrm{C} / \mathrm{N}$ used for aboveground and root biomass were 57, 64 and 41 for maize, wheat and soybean, respectively, determined during some years in the same assays. The average contribution of $\mathrm{C}$ was of 5.7 and 5.6 Mg ha ${ }^{-1}$ year $^{-1}$ under NT and CP in MWS and of 6.0 and $5.6 \mathrm{Mg} \mathrm{ha}^{-1}$ year $^{-1}$ under NT and CP in WS, whereas the average contribution of $\mathrm{N}$ was of 0.11 and $0.10 \mathrm{Mg} \mathrm{ha}^{-1}$ year $^{-1}$ under NT and CP in MWS and of 0.12 and $0.11 \mathrm{Mg} \mathrm{ha}^{-1}$ year $^{-1}$ under NT and CP in WS.

\section{Statistical Analysis}

The effects caused by the tillage treatments on the parameters studied were analyzed for each trial separately for a completely randomized block design. An analysis of variance (ANOVA) using the GLM procedure of SAS [36] was carried out. The means were compared by Tukey's test $(\mathrm{p}<0.05)$.

Simple regression analysis was carried out to explain the relationship between variables, using the procedure REG of SAS [36].

\section{RESULTS}

\section{Depth Distribution of SOC, SON and BD and Total C and N Stubble Biomass}

The tillage systems had no significant effects on BD in any of the depths analyzed. The concentrations of SOC and SON were higher under NT than under CP in the MWS and WS at 0-5 cm, but not in the others depths (Table 1).

SOC and SON stocks at 0-20 cm were: a) in MWS, 45.6 and $4.3 \mathrm{Mg} \mathrm{ha}^{-1}$ under NT and 42.5 and $3.9 \mathrm{Mg} \mathrm{ha}^{-1}$ under $\mathrm{CP}$, respectively, and b) in WS, 44.5 and $4.4 \mathrm{Mg} \mathrm{ha}^{-1}$ under NT and 41.5 and $4.2 \mathrm{Mg} \mathrm{ha}^{-1}$ under CP, respectively (Fig. 1), SOC stock under NT at $0-20 \mathrm{~cm}$ was $7 \%$ higher than under $\mathrm{CP}$ in both rotations, whereas the SON stock under NT at the same depth was $11 \%$ and $5 \%$ higher than under CP in MWS and WS, respectively. The differences between NT and CP expressed as annual average were $10-12 \mathrm{~g} \mathrm{C} \mathrm{m}^{-2}$ year $^{-1}$ and 0.9-1.5 $\mathrm{g} \mathrm{N} \mathrm{m}^{-2}$ year $^{-1}$.

The $\mathrm{C}$ stubble biomass accumulated on the soil under NT was $65 \%$ and $56 \%$ higher than in CP in MWS and WS, respectively, while there were no differences in the $\mathrm{N}$ stubble biomass accumulated on the soil between tillage systems. Under NT, total C and N stocks, including the $\mathrm{C}$ and $\mathrm{N}$ stubble biomass and the SOC and SON at 0-20 cm, showed 4-5 $\mathrm{Mg} \mathrm{C} \mathrm{ha}{ }^{-1}$ and $0.2-0.4 \mathrm{Mg} \mathrm{N}^{-1}$ more than under CP in WS and MWS, respectively (Fig. 1).

\section{Soil Physical and Chemical Properties}

Fig. (2) and Fig. (3) show the differential effect of the tillage systems on the evolution of temperature and water potential

Table 1. Soil Organic Carbon and Nitrogen and Bulk Density Distribution at Three Depths Under Two Tillage Systems in Two Crop Rotations

\begin{tabular}{|c|c|c|c|c|c|c|c|}
\hline \multirow{3}{*}{$\begin{array}{l}\text { Depth } \\
\text { (cm) }\end{array}$} & \multirow{3}{*}{$\begin{array}{c}\text { Crop } \\
\text { Sequences }^{\text {b }}\end{array}$} & \multicolumn{6}{|c|}{ Tillage Systems $\mathrm{s}^{\mathrm{a}}$} \\
\hline & & NT & $\mathbf{C P}$ & NT & $\mathbf{C P}$ & NT & $\mathbf{C P}$ \\
\hline & & \multicolumn{2}{|c|}{$\begin{array}{c}\text { SOC } \\
(\mathrm{g} \mathrm{C} \mathrm{kg} \mathrm{soil} \\
\end{array}$} & \multicolumn{2}{|c|}{ 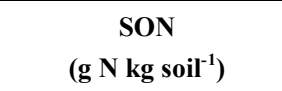 } & \multicolumn{2}{|c|}{$\begin{array}{c}\text { BD } \\
\left(\mathrm{Mg} \mathrm{m}^{-3}\right)\end{array}$} \\
\hline \multirow{2}{*}{$0-5$} & MWS & $24.9 *$ & 20.0 & $2.27^{*}$ & 1.84 & 1.04 & 1.10 \\
\hline & WS & $21.7^{*}$ & 18.4 & $2.03 *$ & 1.80 & 1.18 & 1.14 \\
\hline \multirow{2}{*}{$5-10$} & MWS & 17.8 & 17.4 & 1.71 & 1.60 & 1.23 & 1.22 \\
\hline & WS & 17.3 & 16.4 & 1.71 & 1.66 & 1.26 & 1.24 \\
\hline \multirow{2}{*}{$10-20$} & MWS & 16.3 & 15.5 & 1.59 & 1.43 & 1.33 & 1.35 \\
\hline & WS & 16.4 & 15.8 & 1.70 & 1.63 & 1.27 & 1.32 \\
\hline
\end{tabular}

SOC: soil organic carbon; SON: soil organic nitrogen; BD: bulk density.

* indicate significant differences between tillage systems within the same crop sequence $(\mathrm{p}<0.05)$

${ }^{a}$ NT: no-till; CP: chisel plow.

${ }^{\mathrm{b}}$ MWS: maize-double cropped wheat/soybean; WS: double cropped wheat/soybean. 


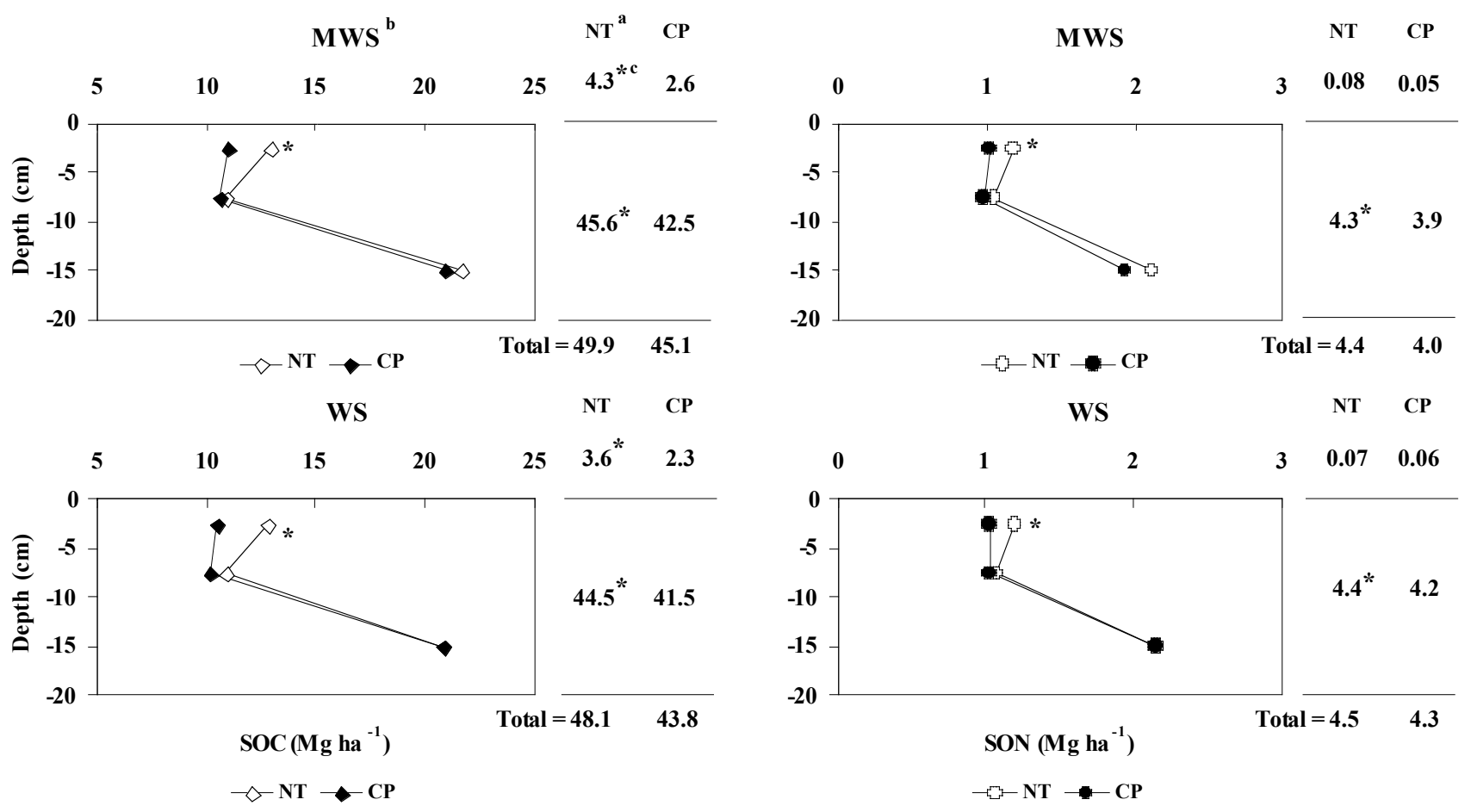

SOC: soil organic carbon; SON: soil organic nitrogen.

* indicate significant differences between tillage systems within the same crop sequence $(\mathrm{p}<0.05)$.

a Tillage systems: NT: no-tillage; CP: chisel plow.

${ }^{\text {b }}$ Crop rotations: MWS: maize-double cropped wheat/soybean; WS: double cropped wheat/soybean.

${ }^{\mathbf{c}} \mathrm{C}$ and $\mathrm{N}$ stubble biomass on soil surface.

Fig. (1). Depth distribution of soil organic carbon and nitrogen stocks under two tillage systems in two crop rotations.
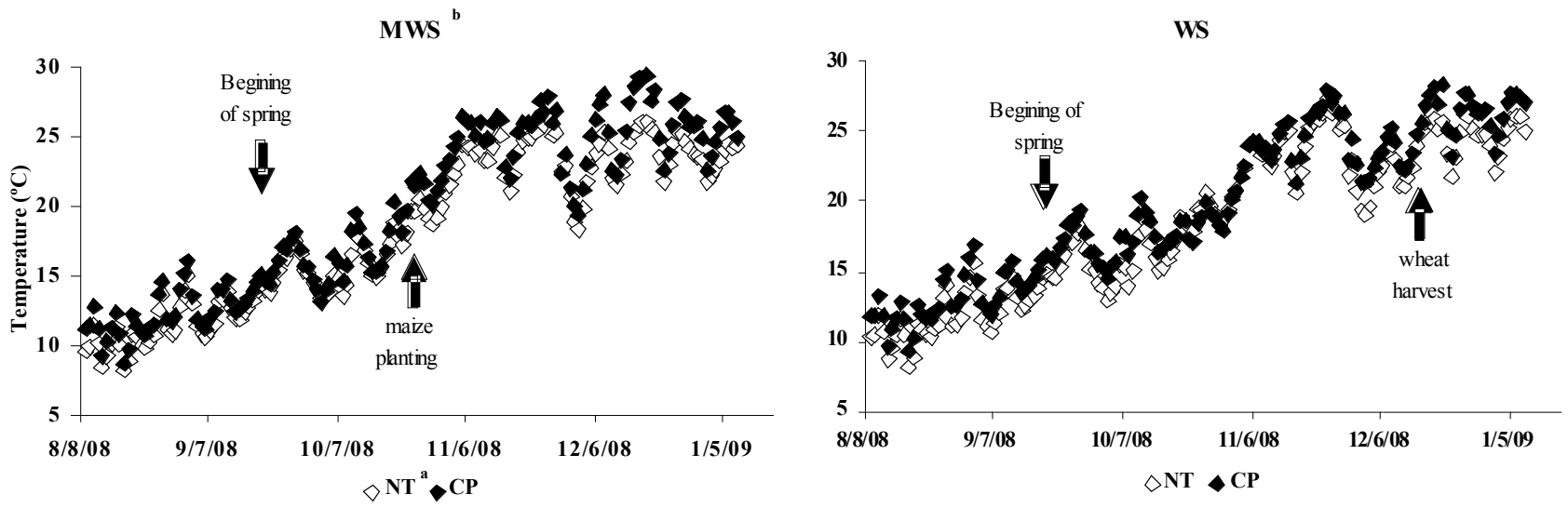

a Tillage systems: NT: no-tillage; CP: chisel plow.

${ }^{\mathbf{b}}$ Crop rotations: MWS: maize-double cropped wheat/soybean; WS: double cropped wheat/soybean.

Fig. (2). Soil mean daily temperature at $10 \mathrm{~cm}$ soil depth under two tillage systems in two crop rotations. Period evaluated: 155 days.

in MWS and WS between the first week of August 2008 and the second week of January 2009. In MWS, the period analyzed included part of the autumn-winter fallow and part of the subsequent cultivation of maize (planted on October $23^{\text {rd }}$ 2008) while in WS, the period covered almost the entire cycle of wheat (planted on July $14^{\text {th }} 2008$ and harvested on December $15^{\text {th }} 2008$ ) and three weeks after this. At $10 \mathrm{~cm}$, under NT, the soil temperature was systematically lower $\left(1.1^{\circ} \mathrm{C}\right)$ than under $\mathrm{CP}$ in both rotations during the period analyzed (Fig. 2). There were no precipitations between the beginning of the measurements and September $30^{\text {th }} 2008$
(Fig. 3). Thus, the potential water decreased in both tillage systems by effect of the evaporation during the fallow of maize and by effect of the evapotranspiration during the growth of wheat. In MWS, the evaporation was lower under NT, while in WS, the evapotranspiration was higher under NT. This occurred during the first fortnight of September and was reversed in the second fortnight, due to the lower increase in temperature under NT than under $\mathrm{CP}$, during a period of sudden increase in temperature. In addition, in the same period, in WS the soil was drier than in MWS. The spring coincided with minor rains, except for the ones occurred 

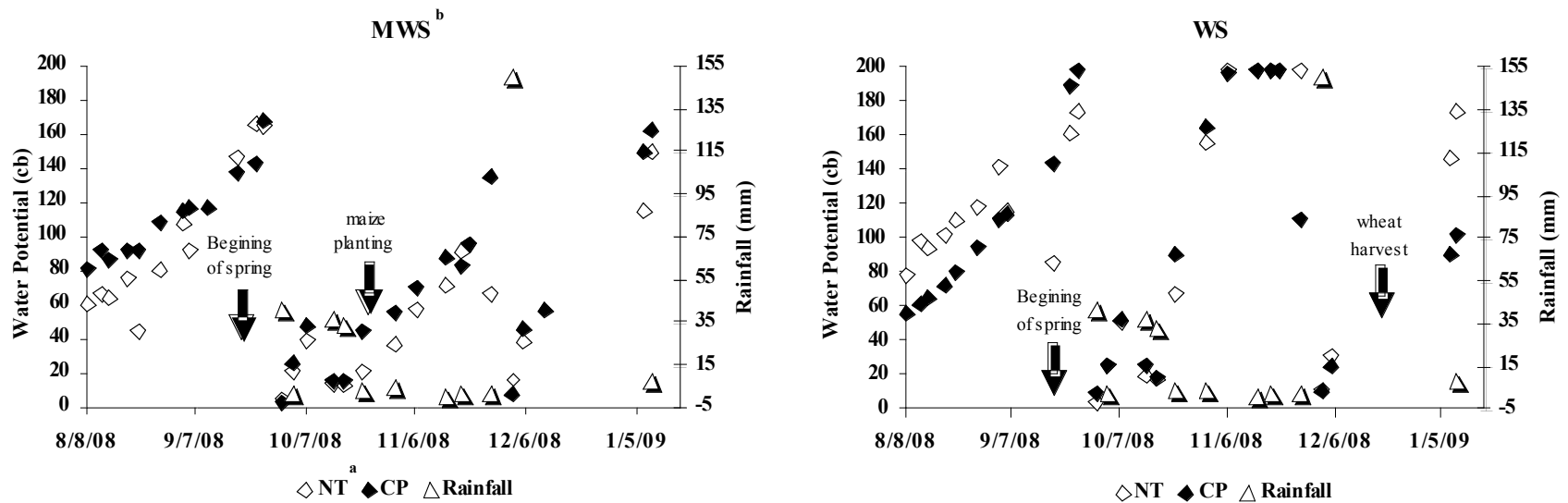

a Tillage systems: NT: no-tillage; CP: chisel plow.

${ }^{b}$ Crop rotations: MWS: maize-double cropped wheat/soybean; WS: double cropped wheat/soybean.

Fig. (3). Absolute value of soil water potential at $10 \mathrm{~cm}$ soil depth under two tillage systems in two crop rotations. Period evaluated: 155 days.

Table 2. Soil Chemical and Physical Properties Under Two Tillage Systems in Two Crop Rotations

\begin{tabular}{|c|c|c|}
\hline \multirow{2}{*}{$\begin{array}{c}\text { Crop } \\
\text { Rotations }^{\mathrm{b}}\end{array}$} & \multicolumn{2}{|c|}{ Tillage Systems $^{\mathrm{a}}$} \\
\hline & NT & $\mathbf{C P}$ \\
\hline & \multicolumn{2}{|c|}{$A S-0-5 \mathrm{~cm}(\%)$} \\
\hline \multirow{3}{*}{$\begin{array}{c}\text { MWS } \\
\text { WS }\end{array}$} & $51.5^{*}$ & 14.5 \\
\hline & $21.9^{*}$ & 10.0 \\
\hline & \multicolumn{2}{|c|}{$A S-5-20 \mathrm{~cm}(\%)$} \\
\hline \multirow{3}{*}{$\begin{array}{l}\text { MWS } \\
\text { WS }\end{array}$} & $22.4^{*}$ & 12.8 \\
\hline & $19.5^{*}$ & 12.9 \\
\hline & \multicolumn{2}{|c|}{$\operatorname{Ir}\left(c m h^{-1}\right)$} \\
\hline MWS & 4.2 & 3.5 \\
\hline \multirow[t]{2}{*}{ WS } & $4.5^{*}$ & 2.7 \\
\hline & \multicolumn{2}{|c|}{$\mathrm{CaCl}_{2} \mathrm{pH}-0-5 \mathrm{~cm}$} \\
\hline \multirow{3}{*}{$\begin{array}{c}\text { MWS } \\
\text { WS }\end{array}$} & 4.98 & $5.36^{*}$ \\
\hline & 4.81 & $5.12 *$ \\
\hline & \multicolumn{2}{|c|}{$\mathrm{CaCl}_{2} \mathrm{pH}-5-10 \mathrm{~cm}$} \\
\hline MWS & 4.94 & $5.23 *$ \\
\hline \multirow[t]{2}{*}{ WS } & 4.93 & 5.10 \\
\hline & \multicolumn{2}{|c|}{$\mathrm{CaCl}_{2} \mathrm{pH}-10-20 \mathrm{~cm}$} \\
\hline MWS & 5.21 & 5.29 \\
\hline \multirow[t]{2}{*}{ WS } & 4.99 & 5.14 \\
\hline & \multicolumn{2}{|c|}{$C E C-0-5 \mathrm{~cm}\left(\mathrm{cmol}_{c} \mathrm{~kg}^{-1}\right)$} \\
\hline MWS & 16.87 & 16.18 \\
\hline \multirow[t]{2}{*}{ WS } & $17.01 *$ & 15.79 \\
\hline & \multicolumn{2}{|c|}{$C E C-5-10 \mathrm{~cm}\left(\mathrm{cmol}_{c} \mathrm{~kg}^{-1}\right)$} \\
\hline MWS & 15.44 & 16.06 \\
\hline \multirow[t]{2}{*}{ WS } & 14.71 & 15.67 \\
\hline & \multicolumn{2}{|c|}{$C E C-10-20 \mathrm{~cm}\left(\mathrm{cmol}_{c} \mathrm{~kg}^{-1}\right)$} \\
\hline MWS & 15.95 & 16.87 \\
\hline WS & 16.22 & 16.13 \\
\hline
\end{tabular}

AS: aggregate stability; Ir: infiltration rate; $\mathrm{CaCl}_{2} \mathrm{pH}$ : proportion soil: solution 1:2.5, CEC: cation exchange capacity.

* indicate significant differences between tillage systems within the same crop sequence $(\mathrm{p}<0.05) .{ }^{\mathrm{a}} \mathrm{NT}$ : no-till; CP: chisel plow. ${ }^{\mathrm{b}} \mathrm{MWS}$ : maize-double cropped wheat/soybean; WS double cropped wheat/soybean. 
Table 3. Particle Size Fractions of SOM Under Two Tillage Systems in Two Crop Rotations

\begin{tabular}{|c|c|c|c|c|c|c|c|c|c|}
\hline \multirow{4}{*}{$\begin{array}{l}\text { Depth } \\
\text { (cm) }\end{array}$} & \multirow{4}{*}{$\begin{array}{c}\text { Crop } \\
\text { Rotations }^{b}\end{array}$} & \multicolumn{8}{|c|}{ Tillage Systems ${ }^{a}$} \\
\hline & & NT & $\mathbf{C P}$ & NT & $\mathbf{C P}$ & NT & $\mathbf{C P}$ & NT & $\mathbf{C P}$ \\
\hline & & \multicolumn{2}{|c|}{ POC } & \multicolumn{2}{|c|}{ PON } & \multicolumn{2}{|c|}{ MAC } & \multicolumn{2}{|c|}{ MAN } \\
\hline & & \multicolumn{8}{|c|}{$\left(\right.$ g kg soil $\left.^{-1}\right)$} \\
\hline \multirow{2}{*}{$0-5$} & MWS & $4.70^{*}$ & 3.22 & $0.35^{*}$ & 0.22 & $20.2^{*}$ & 16.8 & $1.93 *$ & 1.60 \\
\hline & WS & $4.24 *$ & 2.28 & $0.35^{*}$ & 0.16 & $17.4^{*}$ & 16.1 & 1.68 & 1.63 \\
\hline \multirow{2}{*}{$5-10$} & MWS & 1.08 & 1.50 & 0.10 & 0.12 & 16.8 & 15.9 & 1.62 & 1.48 \\
\hline & WS & 1.04 & 1.42 & 0.16 & 0.15 & 16.3 & 15.0 & 1.56 & 1.53 \\
\hline \multirow{2}{*}{$10-20$} & MWS & 0.68 & 0.63 & 0.07 & 0.07 & 15.6 & 14.8 & 1.52 & 1.35 \\
\hline & WS & 0.68 & 0.92 & 0.11 & 0.16 & 15.8 & 14.9 & 1.60 & 1.46 \\
\hline
\end{tabular}

POC: particulate organic carbon; PON: particulate organic nitrogen; MAC: mineral associated carbon; MAN: mineral associated nitrogen. * indicate significant differences between tillage systems within the same crop sequence $(\mathrm{p}<0.05) .{ }^{\mathrm{a}} \mathrm{NT}$ : no-till; CP: chisel plow. ${ }^{\mathrm{b}} \mathrm{MWS}$ : maize-double cropped wheat/soybean; WS: double cropped wheat/soybean.

Table 4. Biological Fractions of SOM Under Two Tillage Systems in Two Crop Rotations

\begin{tabular}{|c|c|c|c|c|c|c|c|c|c|c|c|}
\hline \multirow{2}{*}{$\begin{array}{l}\text { Depth } \\
(\mathrm{cm})\end{array}$} & \multirow{2}{*}{$\begin{array}{c}\text { Crop } \\
\text { Rotations }^{b}\end{array}$} & \multicolumn{10}{|c|}{ Tillage Systems ${ }^{\mathrm{a}}$} \\
\hline & & \multicolumn{2}{|c|}{$\begin{array}{c}\text { MBC } \\
\text { mg C kg Soil }\end{array}$} & \multicolumn{2}{|c|}{$\begin{array}{c}\text { BR } \\
\text { mg C kg Soil }^{-1} \text { hour }^{-1}\end{array}$} & \multicolumn{2}{|c|}{$\begin{array}{c}\mathrm{qCO2} \\
\mathrm{mg} \mathrm{C} \text { kg MBC }^{-1} \text { hour }^{-1} 10^{-3}\end{array}$} & \multicolumn{2}{|c|}{$\begin{array}{c}\text { IAN } \\
\operatorname{mg~N~kg~Soil~}{ }^{-1}\end{array}$} & \multicolumn{2}{|c|}{$\begin{array}{c}\mathrm{MBC} / \mathrm{SOC} \\
(\%)\end{array}$} \\
\hline $0-5$ & MWS & 397 & 387 & 2.5 & 2.1 & 6.4 & 5.7 & 36.6 & 37.9 & 1.60 & 1.93 \\
\hline $5-20$ & WS & $357^{*}$ & 308 & 1.5 & 1.9 & 4.2 & $6.2 *$ & 11.8 & 14.0 & 2.14 & 1.92 \\
\hline
\end{tabular}

$\mathrm{MBC}$ : microbial biomass carbon; $\mathrm{BR}$ : basal respiration; $\mathrm{qCO}_{2}$ : metabolic quotient; IAN: incubated anaerobic nitrogen; $\mathrm{MBC} / \mathrm{SOC}$ : microbial biomass $\mathrm{C} / \mathrm{soil}$ organic $\mathrm{C}$ ratio. * indicate significant differences between tillage systems within the same crop sequence $(\mathrm{p}<0.05)$. ${ }^{\mathrm{a}} \mathrm{NT}$ : no-till; CP: chisel plow. ${ }^{\mathrm{b}}$ MWS: maize-double cropped wheat/soybean; WS: double cropped wheat/soybean.

at the beginning of December. In MWS under NT there was less evapotranspiration than in $\mathrm{CP}$ until the end of the study period. In the case of WS, evapotranspiration increased significantly and there were no evident differences in water potential between tillage systems; however, well advanced the crop cycle, there was a trend towards a greater evapotranspiration under NT; a lower moisture of the soil was also evident under NT in the post-harvest period (Fig. 3). Although wheat yield did not differ between tillage systems, the biomass under NT was higher than under CP (data not shown), confirming a greater evapotranspiration under NT.

The tillage systems affected the following soil properties: $\mathrm{AS}, \mathrm{Ir}, \mathrm{pH}$ and CEC (Table 2). Under NT, there was an increase in $\mathrm{AS}$ at $0-20 \mathrm{~cm}$ in both sequences, although with a more marked increase in MWS than in WS, particularly at 0$5 \mathrm{~cm}$ : 3.6 and 2.2 times greater than under $\mathrm{CP}$, respectively. In the case of MWS, the structure was stable, whereas in WS, the structure tended to be unstable. At $5-20 \mathrm{~cm}$, the structure was clearly unstable under $\mathrm{CP}$, and moderately stable, although close to the threshold of instability, under NT. The $\mathrm{pH}$ was lower under NT than under $\mathrm{CP}$ at $0-5 \mathrm{~cm}$ in both rotations and at $5-10 \mathrm{~cm}$ in MWS. In WS, the Ir and the $\mathrm{CEC}$ at $0-5 \mathrm{~cm}$ under NT were higher than under $\mathrm{CP}$ and showed no differences between tillage systems in MWS.

\section{Physical and Biological Fractions of Soil Organic Matter}

Under NT, the concentrations of POC, PON and MAC were higher at $0-5 \mathrm{~cm}$ than under $\mathrm{CP}$ in both rotations, whereas for POC and PON, the differences between tillage systems were more pronounced in WS (Table $\mathbf{3}$ ). In addition, MAN was higher under NT than under CP in MWS, and there were no differences between tillage systems in either rotation in the remaining soil depths. The differences in MAC and MAN between tillage systems were proportionally less important than those in POC and PON: 20 and $8 \%$ for MAC in MWS and WS, respectively; $21 \%$ for MAN in MWS, 46 and $86 \%$ for POC in MWS and WS, respectively, and 59 and $219 \%$ for PON in MWS and WS, respectively. On the other hand, POC and PON were positively related with AS at $0-20 \mathrm{~cm}$ only in MWS $\left(\mathrm{R}^{2}=0.75\right.$ and 0.78 , respectively, under NT, and $\mathrm{R}^{2}=0.48$ and 0.34 , respectively, under CP).

There was no effect of the tillage system on the biological variables studied in MWS, but the disturbance of the soil in WS increased IAN at $0-5 \mathrm{~cm}$, reduced the $\mathrm{MBC}$ and increased the respiration rate, giving a greater metabolic quotient than under NT at $5-20 \mathrm{~cm}$ (Table 4). The proportion of MBC represented between 1.4 and $2.1 \%$ of the SOC in the two rotations. $\mathrm{MBC}$ was positively related with $\mathrm{SOC}$ $\left(\mathrm{R}^{2}=0.51\right)$, SON $\left(\mathrm{R}^{2}=0.61\right), \mathrm{BR}\left(\mathrm{R}^{2}=0.52\right)$, POC $\left(\mathrm{R}^{2}=0.62\right)$, 
PON $\left(\mathrm{R}^{2}=0.59\right)$ and IAN $\left(\mathrm{R}^{2}=0.63\right)$, whereas IAN was positively related with BR $\left(\mathrm{R}^{2}=0.56\right)$, SOC $\left(\mathrm{R}^{2}=0.52\right)$ and POC $\left(\mathrm{R}^{2}=0.58\right)$, and $\mathrm{BR}$ was positively correlated with POC $\left(\mathrm{R}^{2}=0.60\right)$ and PON $\left(\mathrm{R}^{2}=0.51\right)$ in the two rotations and the two tillage systems.

\section{DISCUSSION}

\section{Effect of the Tillage Intensity on SOC and SON Stocks}

As expected, since NT leaves nearly all the residues on the soil surface and these contribute to the subsequent formation of SOM, the changes in their concentration were recorded closer to the surface of the soil than at greater depths [37]. However, fewer studies have examined changes in SOC and SON stocks [38]. The existence of larger SOC and SON stocks under NT in the rotations for the same mass of soil had already been reported for the year 2004 in the same experiments [11]. In addition, as the diversity of crops (regarding quantity and quality) increases, so does the microbial biomass and the rate of SOM decomposition in the tilled systems, causing a marked decrease in the SOC stocks [39] and, therefore, an increase in the difference between tillage systems in crop rotations. The frequent drying and rewetting of the residues left on the surface increases the resistance of certain nitrogenous compounds against microbial attack and leads to higher $\mathrm{N}$ accumulation near the soil surface under NT [40]. The magnitude of the differences in stock found between tillage systems was of $c a .3$ and $0.2-0.5 \mathrm{Mg} \mathrm{ha}^{-1}$ for SOC and SON, respectively, although there were small changes between sampling years due to random sampling variation.

Since the stocks obtained in 2008 were similar to those found previously [11], the tillage systems seem to have reached a new equilibrium. Generally, the conversion of plow till to no till systems can reach a new equilibrium in a period of 15-20 years [41].

The formation of SOM is a function of the accumulation of decomposed recalcitrant products [42] and is strongly related to the amount of crop residues returning to the soil [43]. Since there were no differences in crop yield between the tillage systems in both analyzed rotations, the return of $\mathrm{C}$ and $\mathrm{N}$ to the soil was not a causative factor in the differences of stocks found.

The factors that explain differences in SOM stocks between tillage systems can be summarized as: a) the periodic disruption of the soil structure, b) changes in the climate of the soil, and c) the incorporation of SOM within the soil matrix [44]. Indeed, we verified that the greater residue accumulation on the soil surface under NT led to the following major changes in the soil: a) a more stable surface structure, particularly in MWS, which protects the organic matter lying within the aggregates from degradation [45]; b) a decrease in the soil temperature, favorable for the preservation of SOM, and changes in water potential that decrease the mineralization rate during the period of wheat [46]; c) a decrease in $\mathrm{pH}$ near of the soil surface, which protects SOM from the microbial attack [13]; and d) greater CEC and Ir in WS, which would indicate a higher proportion of SOM associated with the organo-mineral complex of the soil and its possible transfer in depth. Alvarez and Steinbach [34] reported a high preservation of the organic fraction associated with the min- eral matrix in WS, whereas Radcliff et al. [47] found a greater Ir under NT in the same rotation.

\section{Physical Indicators of Tillage Intensity}

The absence of tillage caused a change in the relative distribution of particulate organic matter (POM) and of the SOM associated with the organo-mineral complex. Results with similar proportions between the two types of SOM fractions were reported by Oorts et al. [48] and Domínguez et al. [49].

The higher MAC and MAN mean values obtained under NT would indicate lower bioavailability of the SOM associated with the organo-mineral complex due to the formation of microbial metabolites and residues which stabilize and accumulate in silts and clays by protective or irreversible adsorption [50]. This represents an expression of the longterm (25-30 years) response of the differential management of the crop residues on this pool of more recalcitrant SOM, which plays an important role in the long-term stabilization of the soil aggregates [51]. The structure stability index used would indicate different mechanisms of stabilization between rotations under NT. The physical protection of the SOM by the soil structure, which represents a very important contribution to the decrease in its mineralization under NT [52] and in which stable aggregates are formed around organic matter of recent incorporation and around POM [53, 54], was particularly important in MWS under NT, where the higher POC and PON stocks were correlated with a stable soil structure. However, in WS, although the aggregate stability and the values of POC and PON were greater under NT than under CP, the soil structure was almost unstable. It is important to point out that the method used to measure the AS does not record the stability of aggregates $<0.5 \mathrm{~mm}$, which could provide the structure with a high stability under WS. It is well known that microaggregates offer better SOM physical protection than macroaggregates $[44,55,56]$.

Although in both rotations under NT the stubble biomass was greater than under $\mathrm{CP}$, in MWS, the difference was more important than in WS. Consequently, although both tillage systems returned similar C masses to the soil, it is likely that in WS there is a greater contact of these residues with the soil, which favors their faster introduction into the soil. Stemmer et al. [57] found that the mineralization of the maize was delayed when the straw was left on the surface and attributed it to the low contact of the residue with the soil. In MWS, part of the maize stalks would be incorporated very slowly because they remain standing after the harvest and because their nature and morphology offers a contact surface with the soil of about half of that of wheat stubble [58]. In WS, the fall of soybean leaves of second sowing with annual frequency from the R6/R7 stage, which have very low $\mathrm{C} / \mathrm{N}$ relationships, stimulates the breakdown of wheat residues and becomes a second nitrogen fertilization of low dose (around $25 \mathrm{~kg} \mathrm{~N} \mathrm{ha}^{-1}$ ) [59] that leads to the formation of labile fractions very processed by fungal activity [60] and would be indicating relatively slower SOM turnover times. Linneres et al. [61] and Lal [62] observed that the contribution of mineral $\mathrm{N}$ to cereal stubbles increased the performance of transformation into stable humus. In addition, the balance between the inputs and outputs of $\mathrm{N}$ from the agrosystem, calculated for the entire period of the crop 
sequences, showed positive values in WS (502 $\left.\mathrm{kg} \mathrm{N} \mathrm{ha}^{-1}\right)$ and negative in MWS (-494 $\left.\mathrm{kg} \mathrm{N} \mathrm{ha}^{-1}\right)$ [11], a fact that would stimulate the humification in WS. On the other hand, working at the Morrow plots (USA), Khan et al. [63] found that after 40-50 years of nitrogen fertilization, when the $\mathrm{N}$ applied to the different crop sequences exceeded by $50-190 \%$ the $\mathrm{N}$ removed by the grain, the SOC stock decreased by means of an increase in its net mineralization. In our case, the $\mathrm{N}$ applied through fertilization in WS exceeded by $31 \%$ the $\mathrm{N}$ removed by the grain for the entire period analyzed. Therefore, no acceleration of the SOM mineralization is expected [11].

\section{Biological Indicators of the Tillage Intensity}

The biological indicators $\mathrm{MBC}, \mathrm{qCO} 2$ and IAN were sensitive to the long-term reduction in tillage intensity only in WS. In MWS, our results were in accordance with those found 15 years before by Alvarez et al. [64], in the same experiment. In this last rotation, the high variability found in the same variables under $\mathrm{CP}$ did not allow finding changes between tillage systems (19 and $17.9 \%, 39.6$ and $29.7 \%$ and 26.6 and $22.5 \%$ at $0-5$ and $5-20 \mathrm{~cm}$ for $\mathrm{MBC}, \mathrm{qCO} 2$ and IAN, respectively). The uneven distribution of the aboveground crop residues (particularly that of maize stalks) introduced into the soil by tilling could be the cause of this high variability. IAN was the variable that presented the greatest variation coefficients. The relationships found between the biological fractions, the labile particle size fractions of the SOM and the SOM indicated that these variables increase with the contents of SOM.

The $\mathrm{MBC} / \mathrm{SOC}$ relationship, used to determine changes in the quality of SOM under different rotations and tillage systems [65], was not sensitive in our study. Several works have shown that, after some years subsequent to the adoption of a conservation tillage system (such as CP and NT) after conventional tillage with moldboard plow, there are increases in $\mathrm{MBC}, \mathrm{MBC} / \mathrm{SOC}$ and $\mathrm{IAN}$, and a relatively marked decrease in $\mathrm{qCO}_{2}$ near the soil surface [65-67]. Some of these changes have also been observed for $\mathrm{qCO}_{2}$ in the long term [68]. Our results in WS showed higher microbial biomass, which consumes less C under NT at $5-20 \mathrm{~cm}$, likely due to a greater transport of transformed organic compounds derived from crop residues at depth. The higher Ir under NT indicates the possibility of increasing the transfer of $\mathrm{C}$ in soluble form or as suspended colloid bound to clay particles from the surface to the deeper layers. The reprecipitation of the soluble $\mathrm{C}$ and its deposition in clay-humic colloids in deeper layers is a mechanism to increase the $\mathrm{C}$ residence time in the soil [69].

Nieder and Benbi [70] have reported contradictory results in relation to the effects of management and of NT on microbial biomass and the associated biological indexes already mentioned. In our case, one possible interpretation of the behavior of these indicators in WS under NT is that in the long-term evolution, the microbial communities that are further away from the surface but in almost constant contact with the rhizosphere of live roots use $\mathrm{C}$ more efficiently, incorporating it to the soil, reducing the intensity of its mineralization and leading to its relative increase in comparison with that observed in $\mathrm{CP}$. The functional biodiversity and activity of soil microorganisms decrease gradually based on the disturbance of the soil from pastures to ploughed soils [71]. The decrease in the efficiency in the use of the substrates in more disturbed situations such as $\mathrm{CP}$ may result from the response of microorganisms to more adverse soil situations, the predominance of zymogen flora over native flora or the alteration of bacteria:fungi relationships, as they present different strategies to use $\mathrm{C}$ [72].

The lower values of IAN under NT at $0-5 \mathrm{~cm}$ in WS may indicate that the $\mathrm{N}$ introduced into the soil by fungal activity consists of less available and labile or more protected substrates than under CP. The soil environment near the surface under NT would originate more recalcitrant organic $\mathrm{N}$ forms [73], reducing its rate of potential mineralization.

In MWS, the maize period is preceded by a relatively extensive period of winter-fall fallow (7 months) which keeps the soil wet and facilitates the mineralization of labile forms of SOM; for the remaining 5 months, with the cultivation of maize, there would be a stable macro-structural porous system by the combined action of the crop roots, the micro-organisms and the soil particles, which remains during the next phase of WS. In the absence of maize (WS), and with relatively short fallow periods (two months), the $\mathrm{C}$ and $\mathrm{N}$ are used more efficiently by microorganisms, leading to the formation of more humified substances and probably protected in aggregates of smaller size than those found in MWS. The inclusion of cover crops of fall-winter cycle to reduce the extensive fallow period during the soybean-maize period in MWS could reduce the mineralization of SOM in this period and increase the $\mathrm{C}$ and $\mathrm{N}$ input to the soil.

The retention of crop residues on the soil in agrosystems managed under long-term NT with average inputs of 5-6 Mg $\mathrm{C} \mathrm{ha}^{-1}$ year ${ }^{-1}$ kept a high content of SOM, especially in the surface layer, which had very important implications for the soil fertility because it improved some of its physical, chemical and biological properties. Besides, other aspects of its management, related to the quality of such residues and the time of occupation of the soil by live roots, were highlighted as factors of stabilization of $\mathrm{C}$ and $\mathrm{N}$. The characteristics of the SOM in WS would be indicating the possibility of achieving slower recycling of $\mathrm{C}$ and $\mathrm{N}$, and therefore, of contributing more effectively to the retention of these elements in the soil-plant system. However, it is necessary to continue evaluating their long-term effect in order to understand future changes in the reserves of SOM, considering a growing increase in the $\mathrm{C}$ and $\mathrm{N}$ inputs due to the genetic improvements of crops and to a further intensification of the crop sequences. The production of wheat residues in these experiments, in general does not exceed $4 \mathrm{Mg} \mathrm{C} \mathrm{ha}^{-1}$ year $^{-1}$. Thus, under the soil-climatic conditions of the Rolling Pampa, a large quantity of wheat residues can quickly enter the soil transformed, in either of the two crop rotations, without accumulating large amounts of stubble on the soil (ca. $\left.11 \mathrm{Mg} \mathrm{ha}^{-1}\right)$. However, in sustained conditions of very high productivity of wheat and maize, the problem of a stubble accumulation that hinders soybean planting immediately after the wheat harvest is starting to be observed in MWS under NT with high fertilizer rates. For these cases, a planned export of part of the residue biomass for the purpose of bioenergy would be taken into account to maintain the productive stability of this agrosystem. 


\section{CONCLUSION}

In the soil and climatic conditions of the Argentine Rolling Pampa, the implementation of a proper management of crop residues has the potential to improve the soil quality and maintain long-term productivity. Intensified crop rotations at a rate of two crops per year or three crops every two years under NT in the long term retained more $\mathrm{C}$ and $\mathrm{N}$ in the soil than when they were disturbed under conservation tillage. However, the two rotations differed in the way to protect them: MWS kept them thanks to a high stability of macroaggregates, whereas WS did so through more humified and transformed ways of slower recycling.

\section{CONFLICT OF INTEREST}

The authors confirm that this article content has no conflicts of interest.

\section{ACKNOWLEDGEMENTS}

We thank Lila Darder, Leticia García, Jimena Dalpiaz, Juliana Torti and Leandro Hanuch for laboratory assistance and Diego Colombini, Fabio Villalba, Fernando Rimatori and Alberto Rondán for field assistance. We are grateful to Carolina Sasal and Silvina Restovich for her constructive comments and suggestions. This study was supported by National INTA and PICT 200421078 projects.

\section{REFERENCES}

[1] Senigagliesi C, Ferrari M. In: Buxton, DR, Shibles R, Forsberg RA, et al., Eds. Soil and crop responses to alternative tillage practices. International Crop Science. WI 53711, USA: Crop Sci Soc Am Madison 1993; pp. 27-35.

[2] Michelena R, Irurtia C, Vavruska F, Mon R, Pittaluga A. Degradación de suelos en el norte de la Región Pampeana. Publ Téc nº, Proyecto de Agricultura Conservacionista. INTA EEA Pergamino 1989.

[3] Asociación Argentina de Productores de Siembra Directa (AAPRESID). [Homepage on the internet] Siembra directa. Historia. Available from: http://www.aapresid.org.ar-/siembradirecta.asp. [cited 2012 Jun 25].

[4] Secretaría de A, Ganadería, Pesca y Alimentos (SAGPyA), República Argentina. [Homepage on the Internet] Available from: http://www.sagpya.gov.ar [cited 2008 Aug 6].

[5] Viglizzo EF, Lértora F, Pordomingo AJ, Bernardos JN, Roberto ZE, Del Valle H. Ecological lessons and applications from one century of low external-input farming in the pampas of Argentina. Agric Ecosyst Environ 2001; 83: 65-81.

[6] Restovich SB, Andriulo AE, Portela SI. Introduction of cover crops in a maize-soybean rotation of the Humid Pampas: Effect on nitrogen and water dynamics. Field Crops Res 2012; 128: 62-70.

[7] Caride C, Piñeiro G, Paruelo JM. How does agricultural management modify ecosystem services in the argentine Pampas? The effects on soil C dynamics. Agric Ecosyst Environ 2012; 154: 23-33.

[8] Andriulo A, Cordone G. In: Panigatti JL, Marelli H, Buschiazzo D, R Gil, Eds. Impacto de labranzas y Rotaciones sobre la materia orgánica de suelos de la Región Pampeana Húmeda. Siembra Directa. Hemisferio Sur 1998; pp. 65-95.

[9] Lavado R. In: Alvarez R, Ed. La región Pampeana: historia, característica y uso de sus suelos. Materia orgánica: Valor agronómico y dinámica en suelos pampeanos. Facultad de Agronomía, Universidad de Buenos Aires 2006. pp. 1-11.

[10] Ferreras L, Toresani S, Bonel B, et al. Parámetros químicos y biológicos como indicadores de calidad del suelo en diferentes manejos. Ciencia del Suelo 2009; 27:103-14.

[11] Irizar A. Cambios en las reservas de material orgánica del suelo y sus fracciones granulométricas: efecto de la secuencia de cultivo, del sistema de labranza y de la fertilización nitrogenada. Tesis de maestría, Universidad Nacional de Buenos Aires: Argentina 2010; p. 123.
[12]

Restovich SB, Sasal MC, Irizar AB, Rimatori F, Darder ML, Andriulo AE. Rotación con maíz vs. monocultivo de soja: efecto sobre los stocks de carbono y nitrógeno edáficos. Trabajo presentado en el VIII Congreso Nacional de Maíz, Rosario, Argentina, 16 de noviembre 2005.

[13] Huggins DR, Allmaras RR, Clapp CE, Lamb JA, Randall GW Corn soybean sequence and tillage effects on soil carbon dynamics and storage. Soil Sci Soc Am J 2007; 71: 145-54.

[14] Andriulo A, Irizar A, García L, Hanuch L, Rimatori F. Efecto de los monocultivos de soja y maíz sobre el aporte de Carbono y algunas propiedades edáficas luego de 20 años bajo siembra directa Trabajo presentado en el XXI Congreso Argentino de la Ciencia del Suelo, San Luis: Argentina, 13 de mayo 2008.

[15] Sasal MC, Andriulo AE, Taboada MA. Soil porosity characteristics and water movement under zero tillage in silty soils in Argentinian Pampas. Soil Till Res 2006; 87: 9-18.

[16] Portela SI, Andriulo AE, Jobbágy EG, Sasal MC. Water and nitrate exchange between cultivated ecosystems and groundwater in the Rolling Pampas. Agric Ecosyst Environ 2009; 134: 277-86.

[17] Sasal MC, Castiglioni MG, Wilson MG. Effect of crop sequences on soil properties and runoff on natural-rainfall erosion plots under no tillage. Soil Till Res 2010; 108: 24-9.

[18] Darder ML, Sasal MC, Wilson MG, Andriulo A, Paz Gonzales A. Pérdida de nitrógeno en sedimentos por escurrimiento bajo distintas secuencias de cultivo en siembra directa. Paper presented at the IV Congreso sobre Uso y Manejo de Suelo, La Coruña, España, July 14, 2010.

[19] Hall RA, Rebella CM, Ghersa CM, Culot JP. In: Pearson CJ, Ed. Field-crop systems of the pampas. Field Crops Ecosystems. Ecosystems of the World. Amsterdam: Elsevier 1992; pp. 413-50.

[20] Instituto Nacional de Tecnología Agropecuaria (INTA). Carta de suelos de la República Argentina. Hoja Pergamino (3360-32) 1972; p. 106

[21] Cambardella CA, Elliot ET. Particulate soil organic-matter changes across a grassland cultivation sequence. Soil Sci Soc Am J 1992; 56: 777-83.

[22] Feller C. Une méthode de fractionnement granulométrique de la metière organique du sol. Application aux sols tropicaux à textures grossières, très pauvres en humus. Cahiers ORSTOM série Pédologie, Paris 1979; 17: 339-46.

[23] Soil Survey Laboratory Staff. Soil survey laboratory methods manual. Soil Surv. Invest. Reps. 42. USDA- SCS, Washington, DC 1992.

[24] Douglas JT, Goss MJ. Stability and organic matter of surface soil aggregates under different methods of cultivation and in grassland. Soil Till Res 1982; 2: 155-75.

[25] Kemper WD. In: Black CA, Ed. Aggregate stability. Methods of Soil Analysis. Part 1. Agronomy, vol. 9. Madison: Am Soc Agron Inc 1965; pp. 511-19.

[26] Vance ED, Brookes PC, Jenkinson DS. An extraction method for measuring soil microbial biomass C. Soil Biol Biochem 1987; 19: 703-7.

[27] Tate KR, Ross DJ, Feltham CW. A direct extraction method to estimate soil microbial carbon. Effects of experimental variables and some different calibration procedures. Soil Biol Biochem 1988; 20: 329-35.

[28] Jenkinson DS, Powlson DS. The effects of biocidal treatments on metabolism in soil. V. A method for measuring soil biomass. Soil Biol Biochem 1976; 8: 209-13.

[29] Anderson TH, Domsch KH. Application of eco-physiological quotients $\left(\mathrm{qCO}_{2}\right.$, and $\left.\mathrm{qD}\right)$ on microbial biomasses from soil of different cropping histories. Soil Biol Biochem 1990; 22: 251-55.

[30] Waring SA, Bremner JM. Ammonium production in soil under waterlogged conditions as an index of nitrogen availability. London Nature 1964; 201(4922): 951-52.

[31] Keeney DR, Nelson DW. In: Page AL, Ed. Nitrogen inorganic forms. Methods of soil analysis. Part 2, Chemical and microbiological properties. Agronomy Monograph 9. Madison, EEUU: Am Soc Agron Soil Sci Soc Am 1982; pp. 643-98.

[32] Burke W, Gabriela D, Bruma J. Soil structure assessment. Rotterdam: A.A. Balkema 1986; p. 92

[33] Ankeny MD. In: Topp GC, Reynolds WY, Green RD, Eds. Methods and theory for unconfined infiltration measurements. Advances in Measurement in Soil Physical Properties: Bringing Theory into Practice. SSSA, Special Publication No. 30, 1992. 
[34] Alvarez R, Steinbach H. In: Alvarez R, Ed. Balance de carbono en suelos cultivados. Materia orgánica: Valor agronómico y dinámica en suelos pampeanos. Facultad de Agronomía, Universidad de Buenos Aires 2006; pp. 55-68.

[35] Bolinder MA, Janzen HH, Gregorich EG, Angers DA, VandenBygaart AJ. An approach for estimating net primary productivity and annual carbon inputs to soil for common agricultural crops in Canada. Agric Ecosyst Environ 2007; 118: 29-42.

[36] SAS Institute Inc. SAS/STAT User's guide, Version 8.2. 4th edition. Cary, NC: SAS Institute Inc 2001; vol. 2, p. 846

[37] Salinas García JR, Hons FN, Matoch JE. Long-term effects of tillage and fertilization on soil organic matter dynamics. Soil Sci Soc Am J 1997; 61: 152-9.

[38] Van den Bygaart AJ, Yang XM, Kay BD, Aspinall D. Variability in carbón sequestration potential in no-till soil landscapes of southern Ontario. Soil Till Res 2002; 65: 231-41.

[39] Luo Z, Wang E, Sun OJ. Can no-tillage stimulate carbon sequestration in agricultural soils? A meta-analysis of paired experiments. Agric Ecosyst Environ 2010; 139: 224-31.

[40] Franzluebbers AJ. In: Magdoff F, Weil RR, Eds. Tillage and residue management effects on soil organic matter. Soil organic matter in sustainable agriculture. Boca Raton, Florida: CRC Press LLC 2004; pp. 227-68

[41] West TO, Post WM. Soil organic carbon sequestration rates by tillage and crop rotation: a global data analysis. Soil Sci Soc Am J 2002; 66: 1930-46.

[42] Gleixner G. In: Flanagan LB, Ehleringer JR, Pataki DE, Eds. Stable isotope composition of soil organic matter. Stable isotopes and biosphere-atmosphere interactions: processes and biological controls. Elsevier: London 2005; pp. 47-68.

[43] Voroney RP, Paul EA, Anderson DW. Decomposition of wheat straw and stabilization of microbial products. Can J Soil Sci 1989; 69: 63-77.

[44] Balesdent J, Chenu C, Balabane M. Relationship of soil organic matter dynamics to physical protection and tillage. Soil Till Res 2000; 53: 215-30

[45] Six J, Elliott ET, Paustian K. Soil macroaggregate turnover and microaggregate formation: a mechanism for $\mathrm{C}$ sequestration under no-tillage agriculture. Soil Biom Biochem 2000; 32: 2099-103.

[46] Campbell CA, Zentner RP, Gregorich EG, Roloff G, Liang BC, Blomert B. Organic carbon accumulation in soil over 30 years in a semiarid southwestern Saskatchewan: effects of crop rotations and fertilizers. Can J Soil Sci 2000; 80: 179-92.

[47] Radcliffe DE, Clark RL, Tollner WE, Hargrove WL, Golabi MH. Effect of Tillage Practices on Infiltration and Soil Strength of a Typic Hapludult Soil After Ten Years. Soil Sci Soc Am J 1988; 52: 798-804.

[48] Oorts K, Nicolardot B, Merckx R, Richard G, Boizard HC and N mineralization of undisrupted and disrupted soil from different structural zones of conventional tillage and no-tillage systems in northern France. Soil Biol Biochem 2006; 38: 2576-86.

[49] Domínguez GF, Diovisalvi NV, Sttudert GA, Monterubbianesi MG. Soil organic $\mathrm{C}$ and $\mathrm{N}$ fractions under continuos cropping with contrasting tillage system on mollisols of the southeastern Pampas. Soil Till Res 2009; 102: 93-100.

[50] Hedges JI, Oades JM. Comparative organic geochemistries of soils in marine sediments. Org Geochem 1997; 27: 319-61.

[51] Bhupinderpal S, Renzel Z. In: Marschner P, Rengel Z, Eds. The role of corp residues in improving soil fertility. Nutrient cycling in terrestrial ecosystems. Berlín Heidelberg: Springer-Verlag 2007; pp. 183-214.

[52] Oorts K, Bossuyt H, Labreuche J, Merckx R, Nicolardot B. Carbon and nitrogen stocks in relation to organic matter fractions, aggregation and pore size distribution in no tillage and conventional tillage in northern France. Eur J Soil Sci 2007; 58: 248-59.
[53] Puget P, Chenu C, Balesdent J. Total and young organic matter distributions in aggregates of silty cultivated soils. Eur J Soil Sci 1995; 46: 449-59.

[54] Puget P, Balesdent J, Chenu C. Dynamics of soil organic matter associated with primary particle size fractions of water-stable aggregates. Eur J Soil Sci 1999; 51: 595-605.

[55] Beare MH, Cabrera ML, Hendrix PF, Coleman DC. Aggregateprotectedand unprotected organic matter pools in conventional and no-tillage soils. Soil Sci Soc Am J 1994; 58: 787-95.

[56] Jastrow JD, Boutton TW, Miller RM. Carbon dynamics of aggregate-associated organic matter estimated by carbon-13 natural abundance. Soil Sci Soc Am J 1996; 60: 801-7.

[57] Stemmer M, Von Lützow M, Kandeler E, Pichlmayer F, Gerzabeck $\mathrm{MH}$. The effect of maize straw placement of mineralization of $\mathrm{C}$ and $\mathrm{N}$ in soil particle size fractions. Eur J Soil Sci 1999; 50: 73-85.

[58] Chesson A. In: Cadisch G, Giller KE, Eds. Plant degradation by rumiants: Parallels with litter decomposition in soils. Driven by nature: Plant litter quality and decomposition. UK: CAB International 1997.

[59] Bortolato MA, Andriulo AE, Colombini D, Villalba F, Hanuch L. Aporte de nitrógeno al suelo de las hojas del cultivo de soja. Paper presented at the XXII Congreso Argentino de la Ciencia del Suelo, Rosario, Argentina, May 31, 2010.

[60] Beare MH, Pohlad BR, Wright DH, Coleman DC. Residue placement and fungicide effects of fungal communities in conventional and no-tillage soils. Soil Sci Soc Am J 1993; 57: 392-9.

[61] Linneres M, Muller JC, Remy JC. Etude de la decomposition des pailles et de tiges de maïs. CR Contrat CEE-INRA, ESE-R-014F 1984.

[62] Lal R. Challenges and opportunities in soil organic matter research. The author Journal compilation. Br Soc Soil Sci Eur J Soil Sci 2009, 1-12, doi: 10.1111/j.1365-2389.2008.01114.x

[63] Khan SA, Mulvaney RL, Ellsworth TR, Boast CW. The myth of nitrogen fertilization for soil carbon sequestration. J Environ Qual 2007; 36: 1821-32.

[64] Alvarez R, Diaz RA, Barbero N, Santanatoglia OJ, Blotta L. Soil organic carbon, microbial biomass and $\mathrm{CO} 2-\mathrm{C}$ production from three tillage systems. Soil Till Res 1995; 33: 17-28.

[65] Islam KR, Weil RR. Soil quality indicator properties in midAtlantic soils as influenced by conservation management. J Soil Water Conserv 2000; 55: 69-78.

[66] Doran JW. Microbial biomass and mineralizable nitrogen distributions in no-tillage and plowed soils. Biol Fert Soils 1987; 5: 68-75.

[67] Jacinthe PA, Lal R. Labile carbon and methane uptake as affected by tillage intensity in a Mollisol. Soil Till Res 2005; 80: 35-45.

[68] Insam H, Haselwandter K. Metabolic quotient of the soil microflora in relation to plant succession. Oecologia 1989; 79: 174-8.

[69] Lal R. In: Bhatti JS, Lal R, Apps MJ, Price MA, Eds. Carbon dynamics in agricultural soils. Climate change and managed ecosystems. Boca Raton, FL: CRC Press, Taylor and Francis Group 2006; pp. 127-47.

[70] Nieder R, Benbi DK. Carbon and nitrogen in the terrestrial environment. Springer Science: Business Media BV 2008; p. 430

[71] Degens BP, Harris JA. Development of a physiological approach to measuring the catabolic divewrsity of soil microbial communities. Soil Biol Biochem 1997; 29: 1309-20.

[72] Dilly O, Much JC. Ratios between estimates of microbial biomass content and microbial activity in soils. Biol Fert Soils 1997; 27: 374-9.

[73] Wang WJ, Baldock JA, Dalal RC, Moody PW. Decomposition dynamics of plant materials in relation to nitrogen availability and biochemistry determined by NMR and wet-chemical analysis. Soil Biol Biochem 2004; 36: 2045-58.

Received: August 11, 2012

Revised: November 25, 2012

Accepted: December 03, 2012

(C) Irizar et al.; Licensee Bentham Open.

This is an open access article licensed under the terms of the Creative Commons Attribution Non-Commercial License (http://creativecommons.org/licenses/by-nc/3.0/) which permits unrestricted, non-commercial use, distribution and reproduction in any medium, provided the work is properly cited. 